\title{
Developing English Learning Materials for Mechanical Engineering Students Using Padlet
}

\author{
https://doi.org/10.3991/ijim.v14i04.12759 \\ Fauzul Etfita ${ }^{(\varpi)}$, Sri Wahyuni \\ Universitas Islam Riau, Pekanbaru, Indonesia \\ fauzuletfita@edu.uir.ac.id
}

\begin{abstract}
Due to emergence of English for Specific Purposes where nowadays English not only a learning material for students but it has become a need for people. Mechanical Engineering graduates are expected to have English ability to compete in job profession. For that reason, it was important to develop English learning material based on the needs of Mechanical Engineering student. The aimed of this research was to develop appropriate English learning materials for the students of Mechanical Engineering Students by using Padlet. Padlet is a web-based interactive application that can be used for communication among students. This research was conducted by using research and development method which involves a preliminary stage and collects information, planning, develop of product and expert validation. The research result was feasible to use based on validation step which was $80 \%$ and categorized very good. The product of this research were six units of English learning materials in the form of spoken and written texts as well as grammar explanation. The activities encourage the students to actively participate in the classroom discussion and be involved in solving the task. This research is expected to give contribution to English learning especially English for Mechanical Engineering students.
\end{abstract}

Keywords - Learning materials, Mechanical Engineering Students, Padlet

\section{Introduction}

There has been an increasing number of research projects in which English for Specific Purposes courses are being offered today in order to meet the ever-growing needs of students from various sectors. From those various researches can be seen that materials play a significant role in the process of teaching and learning. The function of teaching materials can be described as an instrument or tool for educators and learners to use [1]. Good and suitable materials will positively affect the learning process of the learners. Students will feel that the real language of communication is being learned as opposed to the language of the classroom itself [2]. Since materials targeted at supporting the teaching and learning process skills of the learners, it should be intended according to the requirements of the learners. However, the phenomenon showed that most university lecturers in Indonesia still have problems with the accessibility of English learning materials that are suitable for students with particular major. 
Besides, discussing English language teaching and learning resources, students are now equipped with vast materials that are both authentic and designed. Moreover, digitalization often affects English Language Teaching tools in the way learners are linked to the outside world. Nowadays, students have access to an enormous amount of online English materials. But while this is clearly beneficial, it can be a little daunting as well. Students do not always realize where to find the most appropriate materials. The amount of time it takes for lecturers to find, pick and prepare materials can be delayed. This requires a high commitment on the part of all teachers or instructors to make an appropriate choice of English resources. However, some policies of the government or those responsible for the curriculum are not aware of these challenges. As a result, the English teaching and learning process is sometimes not appropriate to the growing demand for the use of English [3].

An interview with some English lecturers of Mechanical Engineering in Universitas Islam Riau has conducted and it has been found that unfortunately English teaching materials are not suitable for students. One of the problems is the materials used by lecturers continue to use general English. There is no particular English vocabulary available, whereas English vocabulary and learning materials will be distinct in each unit that the learners will need in their future occupation. Then, there was no major source for English learning materials. For example, a lecturer could only provide students with a task book compiled from a variety of sources. Using inappropriate materials may discourage students from developing their communication skills, particularly while using English in their field of work's target. If this condition occurs, English teaching purposes will not be attained.

In addition, the materials which is available from some developers sometimes detain the learning process if the media needed to convey the instructional materials are not available. It, of course, becomes a problem in achieving the learning objectives. For example, books as a source of learning materials for students contain the dialogue of listening materials but some of the publishers do not provide listening materials in a compact disc for the buyers, whereas listening materials are very essential for the students. It is therefore essential to develop suitable English learning materials for mechanical engineering students. Suitable materials can make it easier for students to learn English. It is because they learn helpful materials linked to their future work, the materials are appropriate for their requirements.

Furthermore, this scenario requires a strong commitment from all lecturer or instructors to select English resources properly [3]. However, some policies of the government or those responsible for the curriculum are not aware of these challenges. As a result, the process of teaching and learning English sometimes did not meet the growing demand for the use of English. It is not surprising that the competence of English-owned non-English student is relatively low. In line with that, Curriculum designer or developer of materials plays a significant role in generating how the process of teaching and learning is carried out. To satisfy their requirements, there should be a match between the needs of the learners and the design itself.

Moreover, Engineering is one of the eight main occupation in the ASEAN Economic Community, especially mechanical engineering. Regrettably, several needs analysis on English for Specific Purposes in ASEAN showed that mechanical engineering students 
understand that they will require abilities for English communication, both spoken and written, to compete better worldwide. Despite this knowledge and despite the extensive teaching resources in this digital era, materials that promote their future performance in their field are not sufficiently provided with English for specific purpose [4].

Based on the facts mentioned previously, the researcher assumes that it will become a problem if not overcome soon. Those are the main reason why this research and development was conducted. This research was expected to solve the problems by designing appropriate English learning materials for Mechanical Engineering Students by using Padlet application. The product of this study was a set of English material for Mechanical Engineering students which was designed in 6 topics. It was developed by using Padlet Application. It is also completed with appropriate learning activities since the material was developed based on the students' needs with the task-based and communicative approach in teaching and learning process.

\section{$2 \quad$ Literature Review}

English for Specific Purposes has been introduced since English has recognized as global software and become trading language. Many people eager to learn English for a variety of reasons. Some of them want to learn English in order to support their successful work, and some of them need to understand textbooks and articles that have been available in English. At the same time as the demand for English learning increased, it addressed the central point of the learners and their attitudes towards education. The learners' needs and interests in English will affect their desire to learn English and thus the success of the learning process. Teaching ESP then means facilitating the students to determine specific English in which the course is designed based on the students' need [5].

English for Specific Purposes is divided in many definitions. Some individuals define ESP as being merely English teaching for any purpose that might be specified. Others, describing it as teaching English used in academic studies or teaching English for professional or vocational reasons, or as teaching English for non-native English speakers who learn English for particular reasons. However, Specific English is intended to satisfy the learner's particular needs. The aim of the ESP is to provide learners with the kind of language they need in a particular field, vocation or occupation [6]. In line, ESP is described in order to satisfy particular learners ' needs and should use the basic methods and operations of the discipline to which it is subjected [7]. English for Specific Purposes should also focus on the language of grammar, lexis, register, study skills and discourse appropriate to these activities.

Ideas disseminated at the International Conference 2014 in India [8]. It pointed out that recent trends in the ESP have grown beyond the linguistic skills and knowledge needed to perform competently in the target situation. ESP has moved to include the needs of the learner or what the learner must do to learn, incorporating both the starting point of the learner and his or her perceptions. To add, the corresponding skills of the students, whose improvement should be initiated or continued at this stage, are firstly the good reading of the scientific content, secondly the ability to find appropriate ICT 
sources, then the development of skills for contemporary learning techniques, then interdisciplinary, last progress in understanding the subjects at least up to the level of comparison, in example the ability [9] [10].

In addition, [11] mentioned that current developments in creating teaching materials by using technology have increased in terms of both volume and genre. This is the lecturer turn to create appropriate e-learning materials which can meet the students need. Besides, students at the center as well as instructors, climate and content are the basic elements for e-learning. The student is at the forefront of learning experiences, according to new approaches in education. The student is supported by all other components. The emphasis should be on the student before preparing and enabling e-learning. The student plays an active role from target setting to the evaluation stage. In elearning, the students are a person who, according to their own learning speed, is responsible for their own learning according to their own needs and area of interest.

\subsection{Materials development}

In most language programs can be seen that teaching materials takes part as the main element. Whether the lecturer uses a textbook, a module, institutionally prepared materials, or his or her own materials, teaching materials generally serve as the basis for much of the language input that learners receive and the language practice that is practiced in the classroom [12]. Material development is both a field of study and a practical undertaking. As a field it studies the principles and procedures of the design, implementation and evaluation of language teaching materials. As a practical undertaking it involves the production, evaluation and adaptation of language teaching materials, by lecturers for their own classrooms and by materials writers for sale or distribution. Ideally these two aspects of materials developments are interactive in that the theoretical studies inform and are informed by the development and use of classroom materials [13].

Furthermore, before the author may settle on the types of drills, assignments and activities to be used in books, an overall instructional structure must be decided. The profession of scholars or theoreticians has a fairly long history of giving instructions to educators and writers of materials on what to teach and how to teach them. After all, at that time, disqualified methodologies such as audiolingualism or cognitive code approach had widespread support from researchers and theoreticians [14].

\subsection{English learning materials}

English learning materials become a very critical part of teaching and learning English. Lecturer require the students to be exposed to the terms. Beginning from learning what language is, students can use the materials they study to expand their knowledge to explore the language.

[15] specified the use of resources to help learners to learn the language. Materials such as a text book, a workbook, a tape, a CD-ROM, a video, a photocopied handbook, the journal, a paragraph written on a whiteboard can be used or nything that demon- 
strates or teaches you about the language you are studying. The material can be modified, created, or merged, but the content presented must take account of methods and curricula. The materials can be adopted, developed, or adapted, or some combination of the three but the materials being presented have to consider approaches and syllabuses. The other component that can be considered as the content of teaching materials is technology like OHP, slides, video and audio, tape recorders, video cameras, computer software, and visual aids. Such factors impact the material and learning processes [16].

In addition, [17] argue that the materials presented must be accurate, however, and suitable methods and syllabuses must be considered. Propose a set of guidelines for effective teaching materials development. First of all, language is functional and must be contextualized. Second, language development requires commitment to the purposeful use of language. Next, the use of language should be realistic and authentic. After that, the classroom materials will usually be searched for an audiovisual component. In addition, learners need to develop the ability to deal with both written and spoken genres. Efficient teaching materials will then foster autonomy. Next, materials need to be flexible enough for individual and contextual differences. Last but not least, learning needs to engage learners both effectively and cognitively.

\subsection{Needs analysis}

In general terms, need analysis which is also called need assessment refers to the activities involved in gathering information that will serve as the basis for developing some materials that will meet the learning needs of a particular group of students. Needs analysis in the formal and technical sense is relatively new in language teaching circles. However, needs analysis have been conducted informally for years by teachers who wanted to assess what language points their students needed to learn. Need analysis is also mentioned as a process to identify the needs for which a learner or group of learners needs a language and to meet the needs [18]. Moreover, there are two types of specifications [19]. The first is the target needs, relating to what students in the target situation are expected to do. It is possible to further classify the goal needs into three categories. First category applies to necessities, which means that students in the target situation need to know to succeed. The second class is lack, referring to the difference in the target situation between what the students already know and what is required. Third, you want to relate to what students like they need. Training needs are the second type of needs.

It can be inferred that the Need Analysis is not only the starting point for the creation of materials, but also directs the choice of content, assessment and classroom activities. Need Analysis creates data that can be used in a variety of ways, such as assessing a curriculum, setting goals, developing assessments and testing methods, and providing information to an outside agency or entity about a program. 


\section{$3 \quad$ Research Methods}

The subject of this research was the fourth semester students of Mechanical Engineering Universitas Islam Riau. The number of the population was 104 students. From the total population, the researcher took 40 students as representatives of their friends. The best design to construct a good English for specific academic purpose materials for the study is research and development design. This research and development is carried out to design specific topics in the English Specific for Academic Purposes textbook materials. The primary objective of this research is to design instructional materials which are appropriate with the needs of the students of Mechanical Engineering students.

The research design used by researcher in this research is Research and Development (R\&D). Research and Development is a name of one research designs involving the classroom problems, studying recent theories of educational product development, developing the educational products, validating the product to experts, and field testing the product [20]. In Research and Development, the researcher examines the object to get new product and then examines the effectiveness of that new product Moreover it is the name of one research design involving classroom issues, the study of recent theories of product development in education, the development of educational products, the validation of the product by experts and the field testing of the product [21].

In addition, the data gathering technique used observation method and questionnaire as primary method and documentation study as well as interview for supplementary method. Therefore, in designing the model, the researcher used Research and Development approach by adapting Borg and Gall Model.

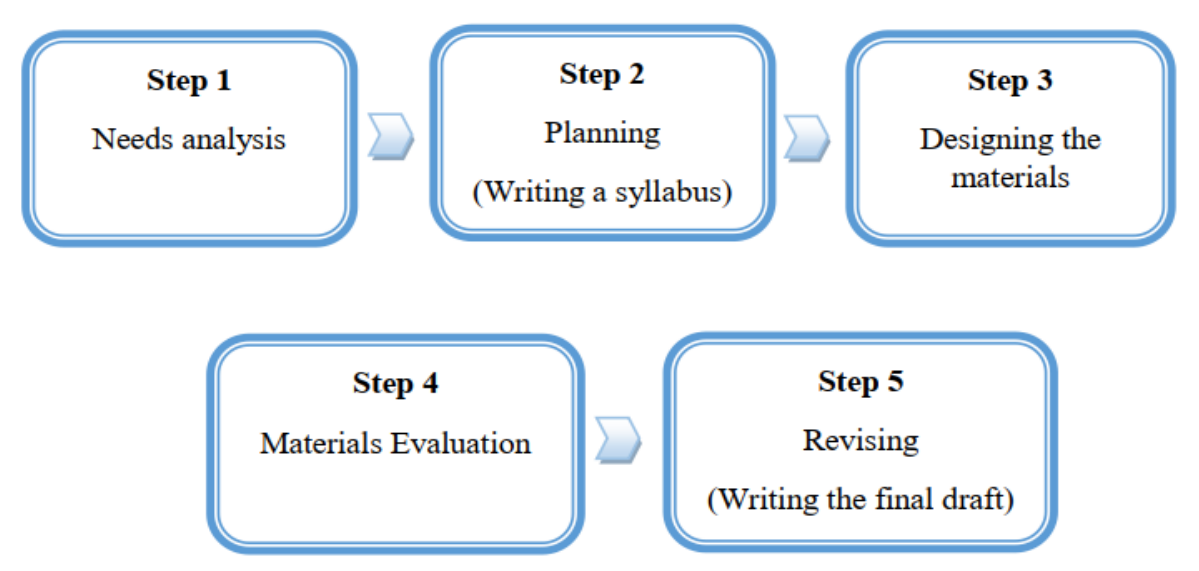

Fig. 1. The Organization of Research Procedures 


\subsection{Research and development procedures}

- Needs analysis: The purpose of the needs analysis is to gather the information of learners' needs and learning needs. The data were analyzed as the basis for developing English learning materials for Mechanical Engineering students.

- Planning: In this stage, the syllabus is developed based on the students' needs analysis questionnaire. The syllabus consists of core competence and basic competence, topics, unit titles, indicators, input texts, language focus that cover vocabulary and grammar, and learning procedure/activities.

- Developing the materials: The development of materials is based on the syllabus.

- Materials evaluation: The materials will be evaluated by an expert to assess the appropriateness of the materials. The process of assessment uses expert judgment questionnaire.

- Revising: The results of the expert judgment questionnaire were analyzed and then used as the basis to rewrite the final draft of the materials. The revisions are based on some categories such as the content, the language, the presentation, and the layout. After being revised, the materials are considered as appropriate English learning materials for Mechanical Engineering students.

\subsection{Try-out product}

Tried-out was done to the target subjects in the real learning and teaching situation in order to evaluate the quality of the developed materials. It is beneficial to find out how far the materials fulfill students' needs. Furthermore, in this phase expert and researcher will work together to evaluate the result of field try-out.

In addition, this research used three kinds of instruments. They are rubric, worksheet, and questionnaire. The rubric is used to evaluate or validate the product. The second instrument is worksheet. The worksheet distributed to the expert which including worksheet for expert's comment and suggestion. The third, the questionnaire is given to students for conducting needs analysis.

In line with the data of this research, there was one way in analyzing obtained data. The data obtained from the students will be analyzed qualitatively. The data from the expert become attachment and notes for the researcher in developing materials in the form of description of the products, comment, notes, and suggestions.

\section{$4 \quad$ Results and Discussion}

As the researcher stated before, need analysis is involved in collecting information that will serve as the basis for developing material that meet the needs of the students.

\subsection{Students' needs}

\section{Necessities:}


Table 1. Students' View about Language Skill to Have

\begin{tabular}{|c|l|l|c|}
\hline \multicolumn{1}{|c|}{ Item } & \multicolumn{1}{|c|}{ Skill } & N & F \\
\hline \multirow{3}{*}{$\begin{array}{l}\text { Students' view about } \\
\text { language skill to have }\end{array}$} & a. listening & 40 & 10 \\
\cline { 2 - 4 } & b. speaking & 40 & 21 \\
\cline { 2 - 4 } & c. reading & 40 & 5 \\
\cline { 2 - 4 } & d. writing & 40 & 4 \\
\hline
\end{tabular}

Table 1 gives information about the proportion of students' view for language skill to have. Overall, the four skills are significantly needed for students. In the first place, 21 of the total number students or about $52.50 \%$ who believed that speaking is the skill which take the most important role for their future job as an Engineer. Secondly, 10 or approximately $25 \%$ students admitted that listening is needed for supporting their future occupation. On the other hand, reading was accounted for about $12.5 \%$ in total number of students. Next, the students decided writing as imperative skill at just $10 \%$.

Lacks: In this point, the gap between the existing proficiency of the students and their target proficiency is called lacks.

Table 2. Students' Current Level of English Proficiency

\begin{tabular}{|l|l|l|l|}
\hline \multicolumn{1}{|c|}{ Item } & \multicolumn{1}{|c|}{ Level } & N & F \\
\hline \multirow{2}{*}{$\begin{array}{l}\text { Students' view about } \\
\text { their current level of }\end{array}$} & a. beginner & 40 & 19 \\
\cline { 2 - 4 } English & b. intermediate & 40 & 18 \\
\cline { 2 - 4 } & c. advance & 40 & 3 \\
\cline { 2 - 4 } & d.others & 40 & 0 \\
\hline
\end{tabular}

The table illustrates the students' English proficiency in four level. There were 19 students or around $47.5 \%$ of total number is still in the beginner level. It means they are only able to comprehend simple sentences and utterances in the daily life, while other 18 students or $45 \%$ of total students' number claimed that they are in the intermediate level. In brief, only 3 of the students are in the advance level.

Wants: Wants refer to the students' view about their needs. The table below describes the students' wants.

Table 3. Students' Want in Learning English

\begin{tabular}{|l|l|c|c|}
\hline \multicolumn{1}{|c|}{ Item } & \multicolumn{1}{|c|}{ Want } & N & F \\
\hline \multirow{4}{*}{$\begin{array}{l}\text { Students' want in learning } \\
\text { English }\end{array}$} & a. able to master vocabulary well & 40 & 11 \\
\cline { 2 - 4 } & b. able to comprehend grammar well & 40 & 15 \\
\cline { 2 - 4 } & $\begin{array}{l}\text { c. able to comprehend and to use every word, sentence, } \\
\text { and utterance }\end{array}$ & 40 & 11 \\
\cline { 2 - 4 } & $\begin{array}{l}\text { d. able to distinguish formal and informal utterances in a } \\
\text { certain text }\end{array}$ & 40 & 3 \\
\cline { 2 - 4 } & $\begin{array}{l}\text { e. others } \\
\text { yyy }\end{array}$ & 40 & 0 \\
\hline
\end{tabular}

The data in the table 3 referees the students' wants in learning. To begin, 15 or around $37.5 \%$ students needed to comprehend grammar well and the other respondents at $27.5 \%$ or 11 students wanted to be able to understand vocabulary well. At the same time, 11 or $27.5 \%$ students admitted to comprehend and use every word, sentence and 
utterance. Meanwhile, 3 or $7.5 \%$ students preferred to able and distinguish formal and informal utterances in a certain text.

\subsection{Description of English learning materials for mechanical engineering}

Materials production: The design of materials requires at least two items to be elaborated. It is a field of study as well as a practical undertaking. It explores the concepts and procedures for developing, implementing and reviewing language teaching materials as a field of study. This includes creating, reviewing and adapting language teaching materials by teachers for their own classrooms and by authors for sale or distribution [22]. This paper explores the creation of materials from the theoretical point of view of its design principles and procedures by means of its practical undertaking to test, adapt, complement and construct its own materials.

In line with that opinion, there are several possible ways of applying materials in the creation of materials: introduction, publishing, and adaptation [23]. In this research, developed materials have been adopted from existing materials to bridge the gap between general English and specific technical English and to introduce more activities. The materials arrangement refers to syllabus which created by the group of English lecturers for Mechanical Engineering major, adapting from existing materials and also considering students' needs.

Framework of the materials: The developed materials designed by researcher namely English Learning materials for Mechanical Engineering students by using Padlet. The materials consist of six topics for fourteen meetings. It provides a clear and coherent unit structure and embodies a view of the nature of language and learning. The Materials has six topics which are contain of four skills, such as Reading, Writing, Listening and Speaking. Those skills are separated in variety of activities. To accommodate students who need more Speaking Activities, vocabulary boxes and link online materials can be used as the solution. Here is the appearance some materials for several meetings:

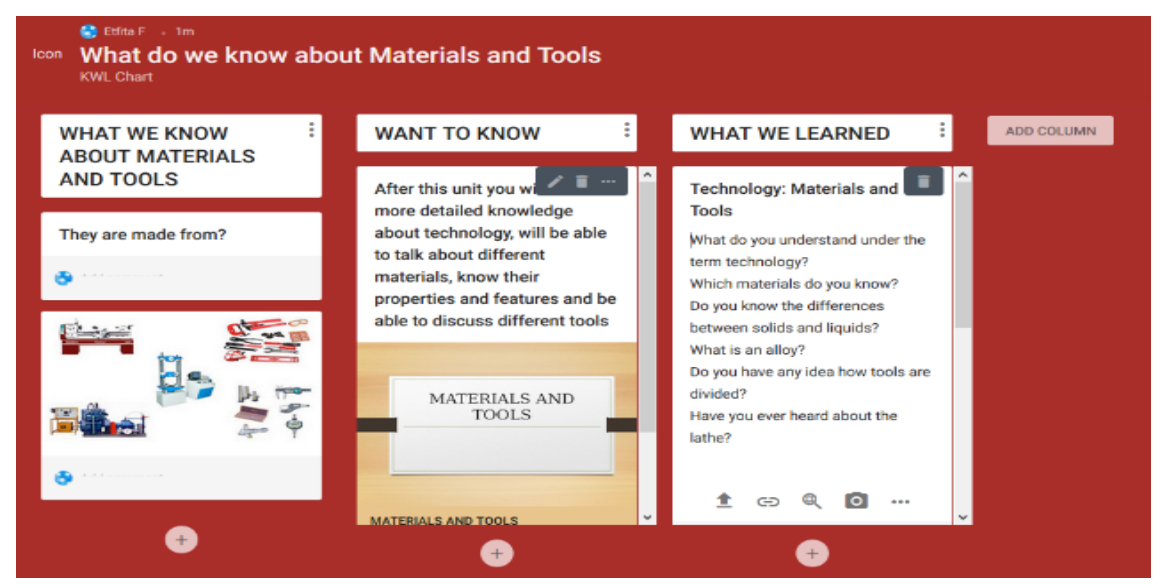

Fig. 2. Snapshot of English Learning Materials 


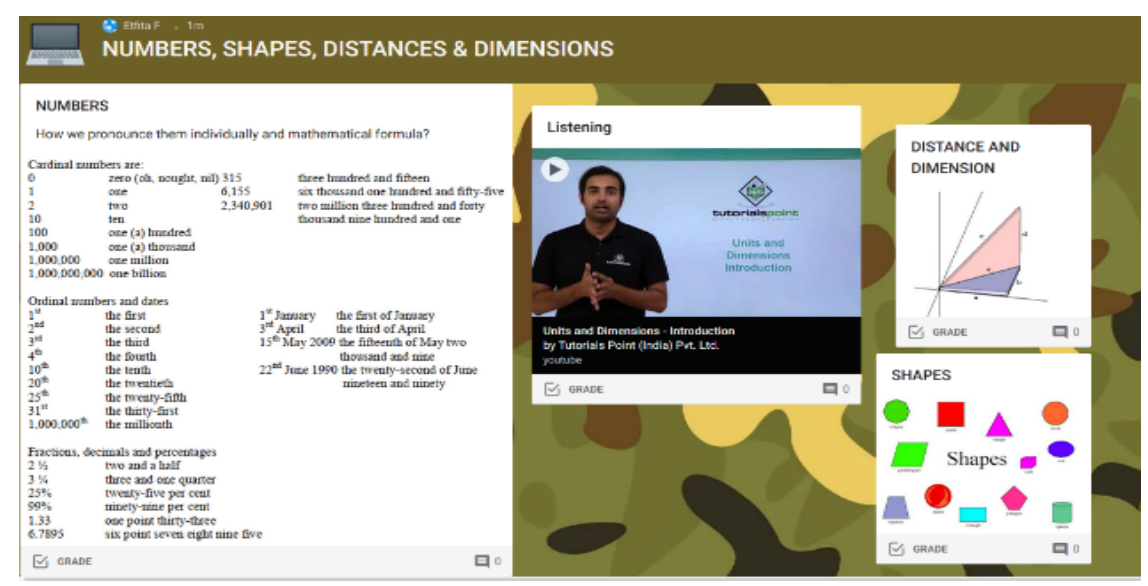

Fig. 3. Snapshot of English Learning Materials

\subsection{The result of the try out}

The results of try out was very good. It can be identified from the questionnaires score which are given to the students. The finding from aspects showed that the English Learning materials were organized attractively, appropriately, logically as well. The table of materials aspects indicated that the quality of materials was very good.

Table 4. Findings Dealing with the Organization of Materials

\begin{tabular}{|l|l|c|c|c|}
\hline \multicolumn{1}{|c|}{ Aspect } & \multicolumn{1}{c|}{ Criteria } & \multicolumn{3}{c|}{ Percentage (\%) } \\
\cline { 3 - 5 } & & Yes & Partly & No \\
\hline $\begin{array}{l}\text { Materials' } \\
\text { Organization }\end{array}$ & The materials are attractively organized. & $90 \%$ & $10 \%$ & 0 \\
\cline { 2 - 5 } & The materials' organization in each chapter is appropriate. & $100 \%$ & 0 & 0 \\
\cline { 2 - 5 } & The materials are arranged in logically ordered tasks. & $92.5 \%$ & $7.5 \%$ & 0 \\
\hline
\end{tabular}

Table 4 provides information on the results of materials' organization. The figure shows the satisfactory level of the first criterion. It was confirmed by the students' percentage. The numbers showed proper, attractive and rational arrangement of the products. The qualification table showed that this aspect's output was excellent.

Table 5. Findings Dealing with the Instructional Objectives

\begin{tabular}{|l|l|c|c|c|}
\hline \multirow{2}{*}{ Aspect } & \multicolumn{1}{|c|}{ Criteria } & \multicolumn{2}{|c|}{ Percentage (\%) } \\
\cline { 3 - 5 } & & Yes & Partly & No \\
\hline Instructional Objectives & The instructional objectives are clear. & $92.5 \%$ & $7.5 \%$ & $0 \%$ \\
\cline { 2 - 5 } & The instructional objectives are understandable. & $90 \%$ & $10 \%$ & $0 \%$ \\
\cline { 2 - 5 } & The instructional objectives are ordered appropriately. & $90 \%$ & $10 \%$ & $0 \%$ \\
\cline { 2 - 5 } & The instructional objectives reflect to the topics. & $92.5 \%$ & $10 \%$ & $0 \%$ \\
\hline
\end{tabular}

The findings of the trial for the second criterion indicate that the instructional objectives are simple, comprehensible and important. The materials represented the topics already, it can be seen from the scores given by students in Table 5 . The qualification 
table showed an excellent quality of this aspect which means that analysis of this criterion was not required.

Table 6. Findings Dealing with the Examples

\begin{tabular}{|l|l|c|c|c|}
\hline \multirow{1}{*}{ Aspect } & \multicolumn{1}{c|}{ Criteria } & \multicolumn{3}{c|}{ Percentage (\%) } \\
\cline { 3 - 5 } & & Yes & Partly & No \\
\hline \multirow{3}{*}{ Examples } & The examples are clear. & $95 \%$ & $5 \%$ & $0 \%$ \\
\cline { 2 - 5 } & The examples are understandable. & $95 \%$ & $5 \%$ & $0 \%$ \\
\cline { 2 - 5 } & The examples are too easy. & $45 \%$ & $45 \%$ & $10 \%$ \\
\cline { 2 - 5 } & The examples are too difficult. & $10 \%$ & $45 \%$ & $45 \%$ \\
\cline { 2 - 5 } & The examples are confusing. & $0 \%$ & $5 \%$ & $95 \%$ \\
\cline { 2 - 5 } & The examples help learners to understand the materials. & $100 \%$ & $0 \%$ & $0 \%$ \\
\cline { 2 - 5 } & The examples deal with the theory. & $95 \%$ & $5 \%$ & 0 \\
\hline
\end{tabular}

The finding for table 6 is categorized in satisfactory level. The numbers showed that the criteria in Example aspect were straightforward, understandable, not too simple or confusing. They also assisted students in understanding the materials and the theory. Therefore, this criterion did not need to be updated. The qualification showed that the standard of this aspect was high.

Table 7. Findings Dealing with the Exercises

\begin{tabular}{|c|c|c|c|c|}
\hline \multirow[t]{2}{*}{ Aspect } & \multirow[t]{2}{*}{ Criteria } & \multicolumn{3}{|c|}{ Percentage (\%) } \\
\hline & & Yes & Partly & No \\
\hline \multirow[t]{14}{*}{ Exercises } & The exercises are understandable. & $95 \%$ & $5 \%$ & $0 \%$ \\
\hline & The exercises are clear. & $95 \%$ & $5 \%$ & $0 \%$ \\
\hline & The exercises are too easy. & $12.5 \%$ & $75 \%$ & $12.5 \%$ \\
\hline & The exercises are too difficult. & $12.5 \%$ & $75 \%$ & $12.5 \%$ \\
\hline & The exercises are appropriate. & $97.5 \%$ & $2.5 \%$ & $0 \%$ \\
\hline & The exercises reinforce what learners have already learned. & $100 \%$ & $0 \%$ & $0 \%$ \\
\hline & The exercises present a progression from simple to more complex. & $100 \%$ & $0 \%$ & $0 \%$ \\
\hline & The exercises are varied in format. & $45 \%$ & $55 \%$ & $0 \%$ \\
\hline & The exercises challenge learners. & $87.5 \%$ & $12.5 \%$ & $0 \%$ \\
\hline & The exercises can be done by the learners. & $97.5 \%$ & $2.5 \%$ & $0 \%$ \\
\hline & $\begin{array}{l}\text { The exercises help the learners to comprehend English morphology } \\
\text { materials. }\end{array}$ & $90 \%$ & $10 \%$ & $0 \%$ \\
\hline & $\begin{array}{l}\text { The exercises help the learners to enhance their ability to under- } \\
\text { stand the theory of word-structure. }\end{array}$ & $90 \%$ & $10 \%$ & $0 \%$ \\
\hline & $\begin{array}{l}\text { The exercises help the learners to improve their ability in analyzing } \\
\text { word-structure. }\end{array}$ & $92.5 \%$ & $7.5 \%$ & $0 \%$ \\
\hline & $\begin{array}{l}\text { The exercises help the learners to enhance their ability in creating } \\
\text { English word. }\end{array}$ & $92.5 \%$ & $7.5 \%$ & $0 \%$ \\
\hline
\end{tabular}

The data in Table 7 showed that the aspect of the exercises was simple, understandable and suitable. It reiterated what the learners had already learned, introduced progress from basic to more complicated, varied in structure, suited the subject being ad- 
dressed, and questioned the learners. Lastly, it helped the learners understand the content, improve their ability to understand the definition of word structure, improve their ability to interpret word structure and improve their ability to write English.

Table 8. Findings Dealing with the Activities

\begin{tabular}{|l|l|c|c|c|}
\hline \multirow{2}{*}{ Aspect } & \multicolumn{1}{c|}{ Criteria } & \multicolumn{3}{c|}{ Percentage (\%) } \\
\cline { 3 - 5 } & & Yes & Partly & No \\
\hline \multirow{3}{*}{ Activities } & The activities are attractive. & $90 \%$ & $10 \%$ & $0 \%$ \\
\cline { 2 - 5 } & The activities are appropriate with the students' ability. & $92.5 \%$ & $7.5 \%$ & $0 \%$ \\
\cline { 2 - 5 } & The activities motivate learners. & $100 \%$ & $0 \%$ & $0 \%$ \\
\cline { 2 - 5 } & The activities are designed for work group. & $80 \%$ & $20 \%$ & $6.67 \%$ \\
\cline { 2 - 5 } & The activities are designed for individual. & $20 \%$ & $80 \%$ & $20 \%$ \\
\cline { 2 - 5 } & The activities can be done by the learners. & $95 \%$ & $5 \%$ & $0 \%$ \\
\hline
\end{tabular}

The results of the trial of the activities were also positive. The data in Table 8 has shown that it is attractive and appropriate. It motivated learners, designed either for group or individual work, were able to do the work of the learners, and varied in format. It has been demonstrated by the student scores. The Qualification indicated that the quality of this aspect was also excellent. There was therefore no need for revision in this aspect.

Table 9. Findings Dealing with the Instructions

\begin{tabular}{|l|l|c|c|c|}
\hline \multirow{3}{*}{ Aspect } & \multicolumn{1}{c|}{ Criteria } & \multicolumn{3}{c|}{ Percentage (\%) } \\
\cline { 3 - 5 } & & Yes & Partly & No \\
\hline \multirow{3}{*}{ Instruction } & The instructions are clear. & $92.5 \%$ & $7.5 \%$ & $0 \%$ \\
\cline { 2 - 5 } & The instructions are appropriate. & $100 \%$ & $0 \%$ & $0 \%$ \\
\cline { 2 - 5 } & The instructions are understandable. & $100 \%$ & $0 \%$ & $0 \%$ \\
\cline { 2 - 5 } & The instructions are confusing. & $0 \%$ & $00 \%$ & $100 \%$ \\
\cline { 2 - 5 } & The instructions are ambiguous. & $0 \%$ & $2.5 \%$ & $97.5 \%$ \\
\cline { 2 - 5 } & The instructions can be done by the learners. & $97.5 \%$ & $2.5 \%$ & $0 \%$ \\
\hline
\end{tabular}

The results of the try out to deal with the instructions aspect were also satisfactory. The data showed that the learners were straightforward, suitable, understandable, not confusing, not vague, and able to do so. It was demonstrated by the students ' scores in Table 9. The qualification table showed that this aspect's quality was excellent. Therefore, in this regard, no revision was required. 
Table 10. Findings Dealing with Coverage of the Materials

\begin{tabular}{|c|c|c|c|c|}
\hline \multirow[t]{2}{*}{ Aspect } & \multirow[t]{2}{*}{ Criteria } & \multicolumn{3}{|c|}{ Percentage (\%) } \\
\hline & & Yes & Partly & No \\
\hline \multirow{7}{*}{$\begin{array}{l}\text { Coverage of } \\
\text { materials }\end{array}$} & The coverage of materials is in line with the syllabus & $90 \%$ & $10 \%$ & $0 \%$ \\
\hline & $\begin{array}{l}\text { The coverage of materials is relevant to the objectives of the } \\
\text { course. }\end{array}$ & $100 \%$ & $0 \%$ & $0 \%$ \\
\hline & The coverage of the materials deal with the aim of the course. & $100 \%$ & $0 \%$ & $0 \%$ \\
\hline & $\begin{array}{l}\text { The coverage of the materials covers both theoretical and practi- } \\
\text { cal points of view of English morphology. }\end{array}$ & $80 \%$ & $20 \%$ & $0 \%$ \\
\hline & The coverage of the materials is understandable. & $90 \%$ & $10 \%$ & $0 \%$ \\
\hline & $\begin{array}{l}\text { The coverage of the materials is appropriate with the students' } \\
\text { interest. }\end{array}$ & $90 \%$ & $10 \%$ & $6.67 \%$ \\
\hline & $\begin{array}{l}\text { The coverage of the materials is appropriate with the students' } \\
\text { needs. }\end{array}$ & $90 \%$ & $10 \%$ & 0 \\
\hline
\end{tabular}

The data related to coverage materials showed that it is understandable and relevant to the interests and needs of the students. Moreover, it is compatible with the course's syllabus, applicable to the course's objectives, mirrored the course's goals, addressing both theoretical and practical perspectives. The scores given by the students proved that this aspect's standard was outstanding. Therefore, the coverage of this aspect was not revised.

Table 11. Findings Dealing with Contents of the Materials

\begin{tabular}{|l|l|c|c|c|}
\hline \multicolumn{1}{|c|}{ Aspect } & \multicolumn{1}{c|}{ Criteria } & \multicolumn{2}{c|}{ Percentage (\%) } \\
\cline { 3 - 4 } & & Yes & Partly & No \\
\hline \multirow{4}{*}{$\begin{array}{l}\text { Content of } \\
\text { materials }\end{array}$} & The content of materials is clear. & $90 \%$ & $10 \%$ & $0 \%$ \\
\cline { 2 - 4 } & The content of materials is appropriate. & $95 \%$ & $5 \%$ & $0 \%$ \\
\cline { 2 - 4 } & The content of materials is understandable. & $97.5 \%$ & $2.5 \%$ & $0 \%$ \\
\cline { 2 - 4 } & The content of materials matches with the goals of the course. & $100 \%$ & $0 \%$ & $0 \%$ \\
\cline { 2 - 4 } & $\begin{array}{l}\text { The content of materials matches with the objectives of the } \\
\text { course. }\end{array}$ & $100 \%$ & $0 \%$ & $0 \%$ \\
\cline { 2 - 4 } & The content of materials matches with the learners' interests. & $90 \%$ & $10 \%$ & $0 \%$ \\
\cline { 2 - 4 } & The content of materials matches with the learners' needs. & $90 \%$ & $10 \%$ & $0 \%$ \\
\cline { 2 - 4 } & The content of materials is well designed. & $100 \%$ & $0 \%$ & $0 \%$ \\
\cline { 2 - 4 } & The content of materials is high quality. & $90 \%$ & $10 \%$ & $0 \%$ \\
\cline { 2 - 4 } & $\begin{array}{l}\text { The content of the materials has covered the standard materials of } \\
\text { English morphology. }\end{array}$ & $75 \%$ & $25 \%$ & $0 \%$ \\
\hline
\end{tabular}

The results of the test with regard to the content of materials were also satisfactory. The data showed that they were understandable and appropriate to the interests and needs of the students. In addition, they were in line with the course syllabus, relevant to the objectives of the course, aligned with the objectives of the course, covering both theoretical and practical points of view. The Qualification Table indicated that the quality of this aspect was excellent. 
Table 12.

Findings Dealing with the Language

\begin{tabular}{|l|l|c|c|c|}
\hline \multirow{2}{*}{ Aspect } & \multicolumn{1}{|c|}{ Criteria } & \multicolumn{3}{c|}{ Percentage (\%) } \\
\cline { 3 - 5 } & & Yes & Partly & No \\
\hline Instructional Objectives & $\begin{array}{l}\text { The language used is appropriate with students' } \\
\text { English proficiency. }\end{array}$ & $90 \%$ & $10 \%$ & $0 \%$ \\
\cline { 2 - 5 } & The language is clear. & $92.5 \%$ & $7.5 \%$ & $0 \%$ \\
\cline { 2 - 5 } & The language used is confusing. & $0 \%$ & $2.5 \%$ & $97.5 \%$ \\
\cline { 2 - 5 } & The language is understandable. & $97.5 \%$ & $2.5 \%$ & 0 \\
\hline
\end{tabular}

The test results showed that the language used was also simple, understandable, acceptable and not inconsistent with the English skills of the students. It was illustrated by the students ' grades in Table 12. The qualification table showed that this aspect's output was excellent. Therefore, there was no need to revise the use of words.

Table 13.

Findings Dealing with the Summaries

\begin{tabular}{|l|l|c|c|c|}
\hline \multirow{2}{*}{ Aspect } & \multicolumn{1}{c|}{ Criteria } & \multicolumn{3}{c|}{ Percentage (\%) } \\
\cline { 3 - 5 } & & Yes & Partly & No \\
\hline \multirow{3}{*}{ Summaries } & The summary is clear. & $95 \%$ & $2.5 \%$ & $2.5 \%$ \\
\cline { 2 - 5 } & The summary is simple. & $97.5 \%$ & $2.5 \%$ & $0 \%$ \\
\cline { 2 - 5 } & The summary is confusing. & $0 \%$ & $0 \%$ & $100 \%$ \\
\cline { 2 - 5 } & The summary is understandable. & $97.5 \%$ & $2.5 \%$ & $0 \%$ \\
\cline { 2 - 5 } & The summary is well-organized. & $97.5 \%$ & $2.5 \%$ & $0 \%$ \\
\cline { 2 - 5 } & The summary is appropriate with the materials presented. & $100 \%$ & $0 \%$ & $0 \%$ \\
\hline
\end{tabular}

The trial results showed that the summaries were straightforward, basic, concise, well-organized, appropriate, and not confusing. Furthermore, the consistency of this aspect was also demonstrated by the qualification table. In short, no revision in this regard was required.

\section{Conclusion}

The finding of this study confessed the need in developing English learning materials for specific purposes, which is, for Mechanical Engineering students. It is also indicated that the results are quite in agreement with the identified needs of the target group of learners. Furthermore, it is found that the participants have different expectations with respect to their needs to use the target language which shows the advantage of needs analysis concerning the identification of the learners' communication skills needs.

\section{References}

[1] S. Ahmed, "Authentic ELT Materials in the Language Classroom: An Overview," J. Appl. Linguist. Lang. Res., vol. 4, no. 2, pp. 181-202, 2017.

[2] R. Hamed Al Azri and M. Hilal Al-Rashdi, "The Effect Of Using Authentic Materials In Teaching,” Int. J. Sci. Technol. Res., vol. 3, no. 10, 2014. 
[3] I. Fitriyah, "Developing English Materials for Islamic Education Students of STAIN Kediri," J. Bhs. Ling. Sci., vol. 10, no. 1, pp. 95-120, 2018. https://doi.org/10.212 74/ls.2018.10.1.95-120

[4] H. Wijaya, "Resource-based Learning: A Paradigm Shift in Materials Design,” vol. 330, no. Iceri 2018, pp. 119-125, 2019.

[5] N. Indrasari, "English for specific purposes : A need analysis at the second semester of physics education students of IAIN Raden Intan Lampung in the academic year of 2015/2016," English Educ. J. Tadris Bhs. Ingg., vol. 9, no. 1, pp. 161-172, 2016.

[6] T. Agustina, "ENGLISH FOR SPECIFIC PURPOSES (ESP): AN APPROACH OF ENGLISH TEACHING FOR NON-ENGLISH DEPARTMENT STUDENTS," J. Beta, vol. 7, no. 1, 2014.

[7] M. Tasić, "English Language Teaching in Mechanical Engineering," FACTA Univ. Linguist. Lit., no. Vol. 7/1, pp. 101-112, 2009.

[8] N. T. H. Nhung, "English for Specific Purposes Modules in Listening and Speaking for Dentistry students," Asian ESP J., vol. 14, no. 1, pp. 1-235, 2018.

[9] R. Repnik and V. Grubelnik, "E-learning materials for 3rd grade of primary school Physics," MIPRO 2009 - 32nd Int. Conv. Proc. Comput. Educ., vol. 4, no. 2, pp. 181-184, 2009.

[10] A. Yundayani, D. Kardijan, and T. Herawan, "Integrating ICT in English for Academic Purposes Materials through Task-Based Approach,” Int. J. Emerg. Technol. Learn., vol. 14, no. 17, p. 29, 2019. https://doi.org/10.3991/ijet.v14i17.10753

[11] F. Ozdamli and E. Ercag, "Opinions of teacher candidates on the usage of mobile applications in the multimedia development processes," Int. J. Interact. Mob. Technol., vol. 12, no. 2, pp. 27-38, 2018. https://doi.org/10.3991/ijim.v12i2.7679

[12] A. Ahmad, "Developing Cooperative Learning Based E-Module to Teach Basic English Grammar of the First Semester of English Study Program Students at FKIP - UIR," $J$. English Acad., vol. 4, no. 2, p. 1, 2017. https://doi.org/10.25299/jshmic.2017.vol4(2).536

[13] J. Nikoopour and M. A. Farsani, "English Language Teaching Material Development," $J$. Lang. Transl., vol. 2, no. 2, pp. 1-12, 2011.

[14] J. C. Richards, "Materials development and research - Making the connection," RELC J., vol. 37, no. 1 , pp. 5-26, 2006.

[15] P. Gantara, D. Ardi, and W. Putra, "Developing English speaking materials integrated Youtube video for Management Department students of Darwan Ali university Sampit," no. November 2018, pp. 16-17, 2019.

[16] Fitriah, “Teaching material," Pastoral Psychol., vol. 6, no. 2, p. 41, 2015.

[17] M. M. Assapari, I. N. Martha, I. M. Sutama, and L. P. Artini, "Developing EFL learning materials for adult learners," Int. J. Linguist. Lit. Cult., vol. 5, no. 3, pp. 32-42, 2019.

[18] A. Alghamdi, "Exploring English Language Needs: Business Students' and Teachers' Perspectives in a Saudi Undergraduate Context," Arab World English J., vol. 1, no. 1, pp. 4-17, 2019. https://doi.org/10.24093/awej/elt1.1

[19] A. S. Elsaid Mohammed and H. S. M. Nur, "Needs Analysis in English for Academic Purposes: The Case of Teaching Assistants at the University of Khartoum," How, vol. 25, no. 2, pp. 49-68, 2018. https://doi.org/10.19183/how.25.2.409

[20] M. K. Nur Ali Mubar, "Developing English Learning Materials for Young Learners Based on Needs Analysis At Mtsn Model Makassar," ETERNAL (English, Teaching, Learn. Res. Journal), vol. 1, no. 2, pp. 313-330, 2015. https://doi.org/10.24252/eternal.v12.2015.a8

[21] A. Halim, "AL-ISHLAH : JURNAL PENDIDIKAN DEVELOPING E-LEARNING MEDIA FOR ESP LEARNING OF ENGLISH FOR NURSING STUDENTS,” vol. 11, no. 2, pp. 243-255, 2019. https://doi.org/10.35445/alishlah.v11i2.158 
[22] Y. M. Harsono, "Developing Learning Materials for Specific Purposes," TEFLIN J., vol. 18, no. 2, pp. 169-179, 2007.

[23] E. Nurhidayat, "Developing English Supplementary Materials through Instructional Conversations," vol. 8, no. 2, pp. 55-67, 2019.

\section{$7 \quad$ Authors}

Fauzul Etfita and Sri Wahyuni are with Universitas Islam Riau, Pekanbaru, Indonesia (fauzuletfita@edu.uir.ac.id).

Article submitted 2019-12-15. Resubmitted 2020-01-16. Final acceptance 2020-01-17. Final version published as submitted by the authors. 